\title{
Florida Dairy Farm Situation and Outlook 20051
}

\author{
Russ Giesy, Albert DeVries, Dave Bray and Dan Webb²
}

\section{Situation}

Dairy farming is an important part of Florida's agricultural industry. UF/IFAS projected that the value of cash receipts from the sale of milk for 2004 was $\$ 409$ million, up 19\% from the $\$ 329$ million reported in 2003 by the USDA. These cash receipts are approximately $6 \%$ of the total Florida agricultural cash receipts and $29 \%$ of all Florida livestock cash receipts.

The Florida Agricultural Statistics Service has indicated that there were about 137,000 dairy cows in Florida in November, 2004. That is down from 140,000 in November, 2003, 147,000 at the start of 2003 and 152,000 at the start of 2002. This decline is consistent with a long term trend showing fewer cows and dairy farms.

The Dairy Business Analysis Program (DBAP) is a cooperative effort of the Universities of Florida and Georgia, Southeast Milk Inc., and Southeast Dairy Herd Improvement Association, Inc. (DHIA). This project annually surveys participating dairy farms about their revenues, expenses, and investments. DBAP data of 2003 showed that the average mailbox milk price received was $\$ 15.89$, compared to $\$ 16.08$ in 2002 and $\$ 18.27$ in 2001 . The total revenues were $\$ 17.66$, total expenses were $\$ 18.27$ and net farm income was $-\$ 0.61$. Further, debt per cow at the end of 2003 was $\$ 2,023, \$ 118$ higher than at the start of the year. This was the second consecutive year of negative average profitability. However, better results are expected for 2004 due to the higher milk price in 2004.

The higher milk prices of 2004 appear to be behind a drop in dairy cow slaughter numbers. USDA announced November, 2004 dairy cattle slaughter at 192,000 head, down 5,000 head from October and 39,000 below a year ago. Slaughter numbers for the first 11 months of 2004 are running 475,000 below the same period a year ago.

Feed prices were higher in 2004 due to high soybean and corn prices. Soybean prices peaked at \$10.64 per bushel in April (the highest price since 1988). By the end of the year, soybeans settled at just over $\$ 5.00$. Corn hit $\$ 3.42$ in July, but reached $\$ 2.00$ by the year's end. It was the record crops causing downward pressures on prices combined with the fact that world supplies rose sharply. DBAP dairies

1. This document is DS179, one of a series of the Animal Science Department, Florida Cooperative Extension Service, Institute of Food and Agricultural Sciences, University of Florida. Original publication date July 11, 2005. Visit the EDIS Web Site at http://edis.ifas.ufl.edu.

2. Russ Giesy, Extension Agent IV; Albert de Vries, Assistant Professor; Dave Bray, Extension Agent IV; Dan Webb, Professor; Department of Animal Sciences, Cooperative Extension Service, UF/IFAS, Gainesville 32611.

The use of trade names in this publication is solely for the purpose of providing specific information. UF/IFAS does not guarantee or warranty the products named, and references to them in this publication do not signify our approval to the exclusion of other products of suitable composition. 
averaged $\$ 7.16$ per cwt. for purchased feed in 2003, $40 \%$ of total revenues. That number is expected to be higher in 2004, but lower in 2005.

\section{Outlook}

Penn State dairy economists predict that the 2005 U.S. milk production will be up $1.8 \%$ over 2004 , based on U.S. cow numbers down $0.3 \%$ and milk per cow up $2.1 \%$ from 2004 levels. Total US milk production has continued its growth through the fall of 2004. Milk per cow and cow numbers continued to outpace the 2003 levels. October 2004 cow numbers topped October 2003 by 26,000 head. Milk per cow was up 15 pounds during October versus a year ago. The approval for Rumensin ${ }^{\circledR}$ (monensin sodium), increased availability of Posilac ${ }^{\circledR}$, and somewhat cheaper feed ingredients are reasons for projected enhancements in milk per cow. Based on that increased production, they estimated 2005 class III average price at $\$ 11.85$ per cwt. Meanwhile, Class III future milk contracts for the first several months of 2005 are generally in the high $\$ 13$ area, with a high of $\$ 14.13$ for February 2005 and a low of $\$ 13.63$ for May 2005.

Southeast Milk, Inc. has predicted milk prices to average approximately $\$ 18.09$ in 2005 , with prices falling through the spring, recovering during summer months and declining again in the fall. Issues that bear watching as the year progresses are: the economy and demand, world growth and strength of US dollar, effect of speculators in the market and changes in US milk supply. These scenarios suggest a year of on-farm milk prices much stronger than those of 2003 but weaker than those of 2004.

\section{Background Information: the Challenge of Dairy Production in Florida}

\section{Production Challenges}

Florida's warm and humid climate is not ideal for dairy cattle that evolved during centuries of selective breeding in the relatively moderate climates of northern Europe. Heat stress has been shown to reduce production by $25 \%$ by reducing feed intake and increasing health problems such as mastitis, lameness and reproductive delay. Mastitis has been estimated to cost producers at least \$300/cow/year. Udder, feet and reproductive health challenges cause the culling of about $35 \%$ of cows each year. Higher replacement costs prohibit some dairies from culling the less productive animals, and this lowers total herd production and profitability.

\section{Economic Challenges}

Florida's dairy producers operate under a difficult economic situation. Despite a geographic difference and a product that's difficult to transport, they increasingly compete in a national and international marketplace. Negotiating consistently profitable milk prices has become increasingly difficult for Florida's dairy cooperative because larger handlers from outside the southeast are pushing to gain market share. Ultimately they would like to control Florida's growing market with its high fluid use and resulting higher price.

The dairy farm economic situation in the 1990s can be characterized as challenging from the standpoint of volatility in milk prices. DBAP data has shown that milk prices ranged from $\$ 15.51$ in 1995 to $\$ 18.56$ in 1998, averaging \$17.41 from 1995-2001. This volatility is difficult for producers since costs of production are much less variable. The same DBAP-participating dairies averaged $\$ 17.61$ total expense per cwt. from 1995-2001. This is about $25 \%$ higher than the national average.

The size of Florida's dairies requires large investments, over $\$ 1.5$ million on average. But the return to invested capital is generally insufficient. The DBAP-participating dairies' average return on assets ranged from $0 \%$ in 1995 to $9 \%$ in 2001. This rate of return discourages new investments. Florida lost a third of its dairy farms in the 1990s.

\section{Environmental Challenges}

Dairies face increased regulation due to social pressure. Larger herds attract the attention of neighbors and activists concerned with odors, flies, and potential losses of nutrients that influence water quality.

The greatest reason for the environmental issues facing Florida dairy producers is the high 
concentration of animals on farmland.

High-producing cows may consume 100 pounds of feed and 50 gallons of water per day. They may excrete 195 pounds of manure and urine. Florida dairies average nearly 730 cows and about $50 \%$ of them raise young replacement cattle as well. Thus, there is an extremely high volume of nutrients flowing through the dairy system. Even minuscule percentages of these nutrients, if lost, could command attention of regulatory agencies. Further, if cow densities on land become fixed by regulatory action, new constraints on herd size will forever limit most farms' opportunity to grow, dooming them to eventual inefficiency and discontinuation.

The cost of nutrient handling systems that will meet the future requirements of environmental regulatory agencies is unknown and perceived to be a major constraint to dairies as they commit to the future. These costs have two parts; (a) the original investment costs of engineering and putting the new systems in place and (b) operating and maintaining the systems well into the future. These systems, incorporating significant levels of new technology, have been implemented to ensure that dairies efficiently handle nutrients in an environmentally friendly manner. New UF/IFAS research projects are studying the feasibility of using manure nutrients as an energy source in the generation of electricity. The UF/IFAS Extension Service is helping to determine the cost of implementing and operating these new systems so as to aid management decisions for these dairies. Also, the information will be valuable to many others that have yet to develop their best responses to environmental regulation.

Size and location differences among dairies significantly affect nutrient-handling-system expense. Additionally, different types of systems have differing initial investment and operating expenses. Dairies that employ such new systems take on a competitive disadvantage because investing in these new systems generally does not generate a positive return.

\section{Opportunity}

Despite these challenges, the future for Florida dairying is strong because of the market. Florida's growing population ensures a demand for fluid milk products, which generate the greatest value in the marketplace. Also, high costs of energy help discourage transportation of fluid milk into the Florida market from areas with product surpluses, such as the upper mid-west and west. There remains a strong future for those dairies that can ensure cows a comfortable and safe lifestyle and show society an environmentally friendly operation while maintaining a profitable business structure in a changing world.

\section{Sources}

- U.S. Dairy Markets and Outlook Archive: www.nmpf.org/meData/outlook.cfm

- National All-Jersey Equity Newsletter: http://www.usjersey.com/NAJ/equitynews.pdf

- USDA's National Agricultural Statistics Service:

Milk Production: usda.mannlib.cornell.edu/reports/nassr/dairy/ pmp-bb/

- Dairy Product Production: usda.mannlib.cornell.edu/reports/nassr/dairy/ pdp-bb/

- Dairy Product Inventories: usda.mannlib.cornell.edu/reports/nassr/other/ pcs-bb/

- Dairy Product Prices: usda.mannlib.cornell.edu/reports/nassr/price/ dairy/

- USDA's AMS Dairy Programs, Federal Order Prices:

Class I:

http://www.ams.usda.gov/dyfmos/mib/ advanprc.pdf 
Others:

http://www.ams.usda.gov/dyfmos/mib/

classprcacnmt.pdf

Federal Order Forms:

www.ams.usda.gov/dyfmos/mib/

price_form_2003.htm

- AMS Dairy Market News (Fluid Sales, Coop. Class I Prices):

www.ams.usda.gov/dairy/mncs/weekly.htm

- USDA's Economic Research Service (Commercial Disappearance, Price Projections, Etc.):

usda.mannlib.cornell.edu/reports/erssor/ livestock/ldp-mbb/

- USDA's Farm Service Agency:

Information on the MILC program:

http://www.fsa.usda.gov/dafp/psd/MILC.htm

Information on the price support program:

-Notices to the industry:

http://www.fsa.usda.gov/daco/notices.htm

Announcements, invitations, etc.:

http://www.fsa.usda.gov/daco/dairy.htm\#Inv

Inventory reports and statistics:

http://www.fsa.usda.gov/daco/reports.htm

- Bureau of Labor Statistics:

Retail prices:

www.bls.gov/

- Federal Register:

Formal notice of regulatory actions:

www.access.gpo.gov/su_docs/aces/

aces140.html
- Chicago Mercantile Exchange Daily Prices:

Cash Cheese and Butter Prices; Milk and

Butter Futures:

http://www.cme.com/dta/hist/

daily_settlement_prices.html?type=com

Daily Dairy Report:

www.dailydairyreport.com/

\section{- Florida Dairy Business Analysis Program:}

Florida's Cost of Production:

http://dairy.ifas.ufl.edu/fldbc.html

http://edis.ufl.edu/ds174 